\title{
Transparency, Good Governance, Ethical Conduct And Accountability As An Instrument To Guarantee Financial Corrupt Free Public Service: The Local Government Experience In Ebonyi State, 2007 - 2015.
}

\author{
${ }^{1}$ Ibeogu, Aloysius. S., ${ }^{2}$ Nkwede, Vincent. I \\ Department Of Public Administration Ebonyi State University, Abakaliki \\ Department Of Public Administration Ebonyi State University, Abakaliki
}

\begin{abstract}
Accountability, transparency and sound moral ethical conduct is one of the instruments required of public servants or officers that promote good governance in public affairs especially at the local government administration. Public confidence in most of the public officers are low and they are often objects of derision, presented as greed and corrupt in Nigerian local government system and public service administration. This paper which seeks to identify the efficacy of accountability, transparency and moral ethical conduct towards ensuring good governance in Nigeria's local government and public service in general. This study adopted survey research design and is anchored on institutional theory as a theoretical framework of analysis. The study established that greed, bureaucratic corruption, financial corruption, low moral ethics and lack of transparency and public accountability are militating against effective local government and public service development in Ebonyi State. It concludes that a reduction in the level of financial corruption, bureaucratic corruption and improved ethical morals and values, will lead to corresponding increase and improvement in local government administration and public service in Ebonyi State. Recommendations were made for re-orientation in our value system; that public officers found to be corrupt should be adequately punished.
\end{abstract}

\section{Introduction}

Society, and Nigerian society and public service is seriously plagued by a lot of ills including corruption, religious intolerance, ethnic chauvinism, crimes of all sorts such as ritual killings, political violence, armed robbery, advanced free fraud and bureaucratic corruption (Okeke, 2004, Ibeogu, 2016). The preponderance of these vices strongly questions the ethical orientations of the Nigerian citizens. But the constitution of the Federal Republic of Nigeria (1999), section 23, aptly provides Nigeria's national ethics as discipline, integrity, dignity of labour, social justice, religious tolerance, self reliance and patriotism. It is presupposed that the acquisition of these virtues will improve our ethical practices and standard especially in public affairs and public governance, but these ethics notwithstanding, many ills still continue to plague the society.

In Nigeria's public service, it is a common knowledge that some public officers turn their offices to private gold mines where series of sordid practices are unleashed. Such practices grossly undermine the integrity of public bureaucracies.

Public bureaucracies (Public Service) in Africa and Nigeria in particular overtime have attracted criticisms for not living up to expectations and such criticisms undermines good governance and engender corruption.

In view of this, a former Prime Minister of India in the 1980's Rajiv Gandhi publicly stated that he believed $85 \%$ of government spending on development within India never reached its intended beneficiaries but was instead lost to corruption at every stage along the way (Gentleman, 2006) cited in Uguru and Ibeogu, 2015. A 2004 survey in Chad showed that $99 \%$ of money earmarked for moral health clinics by the Ministry of Finance never reached its destination (Collier, 2007). In Uganda, a relatively functional African country, "less than 30\% of the funds dedicated to primary education was actually reaching schools" in 1998 (Calderisi, 2006: 163) quoted in Uguru and Ibeogu, 2015. This underlies the numerous studies of corruption in developing countries.

In Nigeria, former heads of states, former governors, and former council chairmen, present and former political appointees have at one time or the other being accused or indicted for embezzling or diverting of fund meant for provision of social infrastructures for the people (Ibeogu, 2016).

To that effect, the quest for efficiency and effectiveness by the public bureaucracies gave rise to series of administrative reforms. The reforms, not withstanding, many concerned stakeholders still strongly feel that public bureaucracies are not effective and transparent in the conduct of public affairs. 
Maintenance of ethical standards at work places is one of the serious problems of the Nigerian public service. There are glaring cases of fraud, embezzlement, looting of treasures, favouritism, falsification, stealing etc in public offices. How public officials could demonstrate proper and approved behavior in the discharge of their functions has constituted a big thorn in the flesh as long as public service delivery is required. According to Mills (1957) utilitarianism, postulation that an act is moral or not depending on the consequences comes to focus here. The fact that the public officers action have stood to be condemned calls for a sort of re-orientation. The enactment of the anti-corruption law to complement other laws and regulation is noteworthy.

Equally, the provision of ethical indices in the constitution of the Federal Republic of Nigeria further points to the felt needs to instill discipline and related virtues in the public service and the polity, as the cultivation of such ethical standards will hopefully institute transparency, accountability and good governance in our public service and national life.

\section{Objectives of the Study}

The objectives of this research include:

I. To ascertain the extent to which transparency and accountability has been able to put a check on financial leakages in the local governments areas in Ebonyi State;

II. To ascertain the extent to which financial management has contributed to the provision of social infrastructures in the local governments;

III. To ascertain the extent to which accountability, transparency and sound ethical conduct have promoted the image of Nigeria's public service.

\section{Scope of the Study}

The study will cover six local governments from the three senatorial zones of Ebonyi State. They include: Abakaliki, Izzi, Ezza South, Ishielu, Afikpo North and Ivo local government respectively. The bases for their selection were premised on the grounds of their proximity and accessibility of the researcher.

\section{Literature Review}

In a study by Adegite (2010) “Achieving Accountability in Financial Management” seeks to establish the causes of poor accountability and financial management in public sector organization. It established that for efficient accountability and financial management, the legislature should champion the cause of accountability since legislators in Nigeria and other developing countries have the constitutional responsibility to ensure that the executive are accountable to the people for the management of public funds. It concluded that for accountability and financial management to be ensured; legislators at all level of government must ensure that appropriate laws and oversight functions are properly performed by them; that the value system should be improved upon, since the failure has resulted to the high level of corruption and lack of public accountability by public officers.

In a related study by Uguru, L.C and Ibeogu, A (2015) "Effects of Bureaucratic Corruption and lack of Public Accountability on Grass root Transformation". The study which was anchored on survey research design, established that accountability is one of the most important ethical values that is required of all bureaucrats for good governance that is in the interest of the public. It further established that bureaucratic corruption and lack of public accountability has negative effect on the effective grass root transformation in Nigeria. The study concludes that a reduction in the level of bureaucratic corruption in Nigeria will lead to a corresponding increase in public accountability by the public servants thereby boosting grass root transformation and public service development. Recommendations were made that Nigeria's bureaucracies should be modified to accommodate the influx of changes in ideas, culture and values, and adapt to new situations or changing circumstances. Again, grass root transformation will be enhanced through proper accountability, if the immunity clause in the constitution is removed for both the bureaucrats and political class in Nigeria.

\section{Theoretical Framework}

The framework of analysis adopted for the study is the institutional theory. Guy Peters (2007: 7) cited in Izueke (2010) defines an institution as a formal or informal, structural, societal or political phenomenon that transcends the individual level, that is based on more less common values, has certain degree of stability and influences behaviour. Institutional theory focuses on the deeper and more resilient aspects of social structure. It considers the processes by which the structures, including schemes, rules, norms and routines become established as authoritative guidelines for social behaviour. Different components of institutional theory explains how these elements are created, diffused, adopted and adapted over space and time; and how they fall into decline and disuse. 
Institutional theorists believe that institutions not only offer and constrain behavioural alternatives, but they also up to certain extent model individual preferences. This means that institutions, directly or indirectly determine the motives guiding individual behavior.

In Nigeria, there are several organizational measures and institutions such as, Nigerian Police Force (NPF) State Security Services (S.S.S) Independent Corrupt Practices and other Related Offences Commission (I.C.P.C) Economic and Financial Crime Commission (EFCC) Audit Alarm Committee, Office of the Auditor General for Local Government, Office of the State Auditor-General and Auditor - General of the Federation and Public Complaints Commission, that work together and in most cases at crossroads in regularizing the participants behavior in local government administration and public service of the state in a certain way with the intent of promoting transparency, ethical behaviours and conduct, accountability and good governance.

\section{The Essence and the Principles of Ethical Value in Achieving Efficiency and Effectiveness in Nigeria's Public Service.}

Transparency - Transparency according to Abubakar (2010) mentioned in Izueke (2010) is openness and adherence to due process. It further stated that transparency ensures that information is readily available that can be used to measure the authorities performance and guide against any possible misuse of power.

For Ibeogu, A, et al (2015), transparency is where nearly all decisions are carried out publicly. Transparency is a means of holding public officials accountable and of fighting or reducing corruption (Wikipedia, 2009). When government meetings are open to the press and the public, when budget and financial statements may be reviewed by anyone; when laws, rules and decisions are open to discussions, they are seen as transparent and there is less opportunity for the authorities to abuse the system to satisfy themselves. When courts of law and the legislative chambers admit the public and when all information about any activity by an establishment is open and freely available, those processes are transparent. Transparent government is the political doctrine which holds that the business of government and administration should be open at all levels for effective public scrutiny, hence President Barack Obama (American President) in his memorandum to the Heads of Executive Department and Agencies, declared that government should be transparent, and for which his administration was committed to creating "an unprecedented level of openness in government". Transparency strengthens democracy, promote efficiency and effectiveness in governance, it promotes accountability and provides information for citizens about what their government is doing. Transparent government is about taking appropriate action consistent with law and policy, to disclose information rapidly in the forms that public can readily find and use (Obama, 2009).

Transparency as stated by Akpa, (1997) quoted in Okeke (2004) implies openness; it is a term that connotes the state of being open to the people..... It is the capacity to trust people including subordinates in order to carry people along. It refers to a condition of complete and free flow of information. A transparent person is one with clean hands, with a tract record of honesty and probity. In the world of transparent persons, the people and the nation come first, and self is last. People are treated fairly and justly because the rulers are upright and easily swayed by ethnic, religious and nepotic sentiment.

\section{Accountability}

Accountability is the responsibility to account for stewardship to an authority or the people.

Accountability constitutes the side of good governance process, it is the degree to which legislative arm, and public officers, gives account of their stewardship, or have to explain or justify what they have done or failed to do.

Accountability is essential for the efficient functioning of the bureaucracy especially as it is the primary and major implementation arm of government. Accountability acts as a quality control device for the local government and public service. The public and the citizens in the public realm can expect to receive the best service. Accountability underscores the superiority of the public will over private interests of those expected to serve and ensure that the public servants behave according to the ethics of their profession.

Accountability is a precept requiring that government's action be reported, explained, and justified to the people from time to time on a consistent basis under the understanding that governance is a contract between the ruler and the ruled... An accountable government is one that carries the people along and therefore can effectively see its policies and programmes implemented.

Accountability is seen as a social relationship in which an actor feels an obligation to explain and justify his or her conduct to some significant other. It refers to answerability for ones actions or behaviour. It involves the development of objective standards of evaluation to assist the owners of an organization to evaluate the performance of duties by individuals and units within the organization (Olowu, 2002) quoted in Agbodike et al (2014).

Further, accountability is the obligation to render an account for a responsibility that has been conferred. This responsibility is judged or measured in terms of clearly articulated code of conduct. Therefore, 
accountability is the state of quality of being answerable for ones actions and conducts in private and public organization.

Since public organizations are established by an Act of Parliament or Orders of the executive arm of government, supported by tax payer's money and expected to meet the needs and aspirations of the citizens, their managers ought to be accountable. Therefore, Public Accountability is the hallmark of modern democratic governance. Democracy remains a paper procedure if those in power cannot be held accountable in public for their acts and omissions, for their decisions, their policies and their expenditures. The principle of public accountability in government works on the basis of the fact that any office holder, especially an electable public office holder, holds his official duties and responsibilities in trust for the people. So, the people deserves to be assured that the resources which they put at the disposal of government, its officials and its agencies, are efficiently, effectively and economically managed, moreover, properly accountable for.

At the local government level, and the public service in general, all categories of workers therein, need to render accounts of their activities to the public. The public in - return, needs to receive substantial accountability reports for proper assessment of their performance in the activities entrusted to them.

\section{Good Morals and Ethical Value Standards in Public Service.}

Ethics which is synonymous with morals connotes customs, habits, and accepted ways of behaviour of an individual or community (Lacey, 1976: 60). He further sees ethic as an inquiry into how men ought to act in general, not as a means to a given end, but as an end itself. For Walkings (1956: 12), ethics is a system of moral principles, while for Hornby (2000: 395) quoted in Ezeani (2006) ethics is a system or moral principle that governs on influences a person's behaviour. Egbeke (1996: 21) cited in Okeke (2004) ethics is a branch of philosophy which seeks to establish and rationally defined a universally valid theory of what is right and wrong, good and bad, which can be used as a set of moral principles guiding human actions. It is believed that ethics attempts to discover why an action is right or wrong. It has to do with a code of conduct or set of principles by which men live or which binds a group of people together. It expects the group so bound together to exhibit uniform and acceptable standards. For instance, there exists ethics of various professions; teaching, medical, nursing, engineering, legal practice and religion etc. Actions by these various professionals are judged by the ethics of their respective professions. In this way, ethics guides and refines the behaviours of a group. Compliance, adherence or conformity with ethical standards gives a profession, its public image. Equally, protection of ethics helps to give a profession its credibility. So, when one infringes or contravenes professional ethics, he is visited with the appropriate punishment. In Nigeria for instance, some teachers (lecturers) have been suspended or dismissed for examination misconduct, some priests (catholic) have been suspended for having carnal knowledge of their faithful, some medical doctors have either been suspended, or their licenses withdrawn for professional misconduct, some judicial officers have at one time or the other been suspended for exhibiting unethical conduct, such as rash granting of ex - part orders, most recently, about forty-one (41) military officers in Nigerian army were either dismissed or demoted for encouraging electoral frauds on the election day.

Ethics as an important factor in the discharge of private and public service, Section 23 of the Nigerian constitution (1999) provides that Discipline, Integrity, Dignity of Labour, Social Justice, Religious Tolerance, Self-reliance and Patriotism shall be the National ethics for Nigeria.

\section{Relevance of Ethics in Public Service Administration.}

There abound many reasons why ethics are important in Public Administration;

$\checkmark$ Sporadic treatments of ethical questions that arise in the work of public administration today fall short of the expectations of the citizens. The citizens expect government to be ethical just as they expect from any other kind of business;

$\checkmark$ The importance of public administration for modern man. The modern state not only keeps order and supervises the economy; it more than ever has an active role in our live. There is practically no segment of man's life covered by public administration that does not require ethical solution;

$\checkmark$ Bonzek (1991) cited in Ezeani, (2006), administrative ethics is important because of the facts that today's public managers face increasingly complex ethical dilemma, often having to weigh personal and professional values against current public opinion and the law. They require ethical values to guide their conduct and decisions;

$\checkmark$ The pressure which organizations mount on their employees is another factor. Hierarchy tends to push employees in an organization to conduct them in way that pleases management. According to Cooper and Bonzek, (1991: 19-23). 
The tendency of hierarchical organizations to demand absolute loyalty to the superior and thereby displace other important values, even those associated with the formal goods of the organization is a well documented phenomenon.

\section{Politics and Good Governance}

Politics being an art of governing a city, state or nation is aimed at empowering people for self development and development of the society for the common good and the welfare of all.

Many variables are responsible for any government (local, state and federal) to be referred to as good or bad. The concept of good or bad is more or less an ethical issue which today's politics tends to undermine. Ethically, the concept of good has to do with what is right and what ought to be the case.

The ability on the part of government to carry everyone on board regardless of social status, ethnic, religious and political affiliations and to maximize the human and natural resources for the benefit of all in the society is an important indicator for good governance. Good governance requires a moral climate that is conducive to self - actualization, mobilization for effective participation and empowerment of all for the building of a united nation, which one could be proud to associate with.

As new crop of leaders emerge, (elected or appointed) in the public service (government) we are yearning for political leaders with a shepherd's heart, a mother's heart, a father's heart and a heart filled with love to be able to lead all Nigerians to the good pasture of justice and genuine reconciliation, where true peace and prosperity are to be found. We yearn for leaders whose government will make democracy work by providing a regular consultative forum for a meaningful dialogue between the government of the day and its people. Such a forum can go a long way in bringing the government closer to the people and providing opportunity to the people to express their views, offer useful suggestions to government and freely make known their needs. The peoples' need can inform the government on the kind of projects and programmes to embark on for the development of the nation. Government should not carry out projects and programmes based on mere assumptions or for their personal enrichment or self glorification.

As leaders who are close to the people and sensitive to their needs, the poor and the less privileged that have lost a place in our society today will have a special place in their hearts and agenda. The government should formulate practicable policies that can target those categories of people so as to carter for their welfare. Government should thoroughly supervise and evaluate its projects and programmes to ensure that they are effectively carried out or implemented, and those public goods such as fertilizers, agricultural loans, job opportunities and rural infrastructure benefit all.

The provision of people basic needs such as housing facilities, water, electricity, education, healthcare; eradication of poverty and commitment to the economic and technological advancement of the people by the government are other important variables for good governance.

Good governance calls for effective on-going education and formation of the youths who are the leaders of tomorrow. Only a wise and visionary government caters for youth welfare and development. It is therefore necessary to constantly engage the youths in useful activities. This will prevent them from being used individuals or groups who would like to destabilize the society for political, ethnic or religious reasons.

Good governance entails government ability to guarantee the protection of life and property of its citizenry. Political leaders should know that politics is not business or for self gratification but service. Politics as good governance is for promotion of the culture of life, civilization of love, empowerment and community mobilization for holistic development of public service of the state and Nigeria, making it a home for all.

Analysis of Poor Accountability and Transparency in Management of Local Government and Public Service Administration, Ebonyi State Local Government Experience 2014 - 2015.

\begin{tabular}{|c|c|c|c|}
\hline $\mathrm{S} / \mathrm{N}$ & Local Government Area & Name of the Chairman & Misappropriated Amount \\
\hline 1 & Abakaliki & Hon. Batholomew Ottah & $\# 23 \mathrm{~m}$ \\
\hline 2 & Ebonyi & Hon. Paul Iganga & $\$ 43 \mathrm{~m}$ \\
\hline 3 & Izzi & Arc Godwin Nwogbaga & N93m \\
\hline 4 & Afikpo South & Mr. Egwu Chima & $\mathrm{N} 64 \mathrm{~m}$ \\
\hline 5 & Afikpo North & Hon. Anthony Ekoh & $\Uparrow 57 \mathrm{~m}$ \\
\hline 6 & Ohaukwu & Hon. Mrs. Chinyere Elom & $\mathrm{N} 33 \mathrm{~m}$ \\
\hline 7 & Ezza South & Hon. Edwin Okeh & $\Uparrow 40 \mathrm{~m}$ \\
\hline 8 & Ezza North & Hon. Jeff Ogbu & $\$ 72.1 \mathrm{~m}$ \\
\hline 9 & Ivo & Hon. Joseph Obasi & $\$ 99.4 \mathrm{~m}$ \\
\hline 10 & Ohaozara & Hon. Chaka Nweze & N49m \\
\hline 11 & Onicha & Barr. Mrs. Chinyere Nwanoke & $\mathrm{N} 62 \mathrm{~m}$ \\
\hline 12 & Ikwo & Hon. Moses Nwekoye & $\Uparrow 79 \mathrm{~m}$ \\
\hline 13 & Ishielu & Barr. Stanley Odanwu & $N 24.6 \mathrm{~m}$ \\
\hline
\end{tabular}

Source; Ebonyi State House of Assembly Committee Report Investigation on Spending of Local Government Allocation by Local Government Chairmen in Ebonyi State between Nov 2014 - May 2015. 
In a similar vain, Chief Austin Edze was appointed the Executive Chairman of Ebonyi State Universal Basic Education Board in 2002. He ran the affairs of the board between 2002 - 2008, he was however relieved of his appointment by Elechi's administration for what government directives termed "high level corruption".

A technocrat and seasoned educationist, Chief Mike Ogbuzur was appointed in 2008 to replace him. He stirred the ship of the board (EBSUBEB) between $2008-2010$. He was in 2010 relieved of his appointment by what government referred to "his action was inconsistent with the mandate of his office".

From discussion and analogy, these officials lacks the principle of transparency, accountability and ethical conduct to manage and gurrantee effective, efficient and a healthy public service (Ibeogu, 2015).

\section{Summary of Review and Findings}

Considering the various homilies on transparency and accountability by government and preachers of the gospel, and the measures put in place to evolve national ethics and sustain same, they appear not to have been any impact, rather, people, civil and public servants, and political office holders, device new strategies to circumvent them. This appears to be the cause of poor state of affairs, ethical and the low morale and productivity in the states (Nigeria) local government and public service.

The assessment of the Anti - Corruption Law and the state of affairs in Nigeria, since the institution and enactment of the anti - corruption laws, there appears to be an astronomical crescendo in the spate and tempo of corruption in the country. The public office holders have consistently parted company with their oath of office with regard to public funds, driven by greed; they made deep treasure excavations from the public purse. The implication of the above is that our society and public service is still inundated with corruption, as it implies that the demonstration of transparency, accountability and good governance by our public office holders seems quite preposterous.

\section{Recommendations}

In order to ensure that Nigeria's national life and ethics are realized, the following are suggested;

1) $\mathrm{Re}$ - orientation of our value system;

2) Public office holders found to engage in corrupt act should be adequately punished, hence the call for the removal of immunity clause;

3) Ethical values should be made a course of study in our schools across all levels of study;

4) The anti-graft agencies should be strengthened to do their work without fear or favour;

5) Violators of the ethical standards in the public service should be discouraged and disengaged without delay;

6) There is the need for continuous public enlightenment on the importance of public morality, the expectations of the government and the people, the need for modesty, and condemnation of too much demands on the public office holders by their people. Perhaps, it is the desire to meet some of such outrageous demands that accounts or accentuates to corruption;

7) Eradication of poverty in Nigeria is imperative. Poverty could lead to some unwholesome acts including negative tendencies towards accountability;

8) Government should restructure such bodies as the National Orientation Agency (NOA) to make them more functional. This is because their existence and activities are rarely known.

\section{References}

[1]. Adegite, E (2010) Accountability and Financial Management in the Local Government Administartion. Unpublished Project, Department of Public Administration, University of Maidugiri.

[2]. Agbodike, F.C and Udenze, U.M (2014) Factors Militating Against Financial Accountability and Effective Store Control in Local Government Areas in Anambra State Nigeria (2003 - 2011) Review of Public Administration and Management, Vol 3, (6)

[3]. Ebonyi State House of Assembly Committee Report 2015

[4]. Ezeani, E.O (2006) Fundamentals of Public Administration. Enugu: Zik Chuks Publication.

[5]. Ibeogu, A (2015) Assessment of Education Policies in Ebonyi state: A Ph.D Proposal Submitted, Public Administration Department, Ebsu.

[6]. Ignatius Kaigama (2006) A Pastoral Message to the Catholic Diocese of Jos; "Politics for Good Governance. Jos; Catholic Communication.

[7]. Izueke, E.M (2010) "Local Government Administration and Good Governance in Nigeria" Nigerian Journal of Public Administration and Local Government. Vol xv (2)

[8]. Okeke, C (2004) National Ethics and the Quest for Accountability and Transparency in Public Institutions in Nigeria. African Journal of Political and Administrative Studies Vol 1(1)

[9]. Onyekachi, E (2011) Elechi Sacks UBEB Chairman. Government House Press Release Abakaliki.

[10]. Onwe, S., Ibeogu A, and Nkwede, J (2015) Imperatives of Legislative Oversight Function in Nigeria Democratic System. Research on Humanities and Social Science, Vol 5(4)

[11]. Uguru, L.C and Ibeogu, A (2015) Effect of Bureaucratic Corruption and Lack of Public Accountability on Grass root Transformation in Nigeria. African Journal of Politics and Administrative Studies (AJPAS) Vol 6, (1) 